\title{
ETHICAL ISSUES IN CLINICAL TRIALS IN CHILDREN
}

\author{
${ }^{1,2,4}$ Glasa, J. $-{ }^{1,4}$ Glasová, H. $-{ }^{3}$ Glasová, M. $-{ }^{2}$ Krčméryová, T. \\ ${ }^{1}$ Comenius University in Bratislava, Faculty of Medicine, \\ Institue of Pharmacology, Clinical and Experimental Pharmacology \\ ${ }^{2}$ Slovak Medical University in Bratislava, Faculty of Nursing and of Professional \\ Health Studies, \\ Institue of Health Care Ethics, \\ ${ }^{3}$ Comenius University in Bratislava, Faculty of Pedagogy, \\ Institute of Psychology and Logopaedy Studies \\ ${ }^{4}$ Institue of Medical Ethics and Bioethics n. f., Bratislava,
}

\begin{abstract}
Clinical trials (CTs) in children involve much methodological specificity that are reflected in the ethical issues related to them, as well as in the evaluation of ethical acceptability of the given protocol by an ethics committee. A child in comparison to an adult exhibits numerous patho/physiological differences that are in addition characterized by the quick changes during the child's growth and development. Nowadays, there are no doubts about the necessity of conducting specific CTs in children that are not possible to perform in adults. Despite children are not able to give legally valid informed consent and it is necessary to obtain consent from the child's parents, or from the legal representative, it is also necessary, before including the child into the trial, to obtain his/her appropriate agreement (assent) with participation. It is a must always to fully respect the requirements of minimization of pain, discomfort, fear, and separation from the parents especially from the mother. Special ethical issues are connected with CTs conducted in neonatal period. On the part of the professional public, producers of medicinal drugs, as well as from the positions of the European institutions, considerable attention is being paid to the area of CTs in children. It is reflected in numerous scientific researches, and professional and legislative activities. In the Slovak Republic, the area of biomedical research, including CTs, in children and minors is covered by up-to-date, comprehensive legislation. It ensures not only the maximal protection of the child or minor taking part in biomedical research or CT, but it also provides sufficient level of legal certainty to the sponsors and investigators of biomedical research projects/CTs.
\end{abstract}

Keywords: Clinical trials - Children - Ethics - Ethics committees - Informed consent 


\section{INTRODUCTION}

The necessity of evidence-based information to be used in guiding effective and safe medicinal drugs use in children has been recognised long ago. Because of methodological, ethical and legal difficulties of conducting biomedical research, including medicinal drug/s clinical trials (CTs) in children. Such information has been mostly lacking for the most of medicinal drugs used in paediatrics. Therefore, the use of most medicinal drug therapies in children has been, in fact, considered "empirical", i.e. based on extrapolations of information gathered from CTs in adults, or based on the clinical experience of an individual physician, or group of physicians. This situation, long being perceived unsatisfactory, has prompted respective European authorities, led by the European Commission and European Medicines Agency (EMA), to take various initiatives aimed to tackle accumulated problems in this area and push for necessary improvements and solutions. Within the previous decade, considerable progress has been achieved enabling development and implementation of novel methodological, ethical and legal pre-requisites of effective and ethically acceptable conduct of biomedical research, including CTs, in children [2, 3, 10, 13]. Ethical appraisal has been both a part and an evaluation component of most of these initiatives, as well as of the legal or ethical guidance documents produced [9].

In this paper, we give a brief overview of ethical issues that are most frequently encountered in the planning, design, preparation, conduct and evaluation of CTs in children in general, based on the seminal European documents in the field. Subsequently, we comment on the situation as seen in this area in the Slovak Republic (SR). As this topic is seldom commented upon in the national professional literature in $\mathrm{SR}$, we understand our contribution in terms of an invitation to a broader discussion of these issues among interested or concerned professionals and relevant SR institutions and organizations.

\section{CHARACTERISTICS OF CLINICAL TRIALS IN CHILDREN}

We bring a brief outline of the most important characteristics of the CTs in children, especially those that should be in mind from the point of view of specific ethical issues they may rise in this 'by definition' vulnerable population as compared with the situation in adults. We base this sketchy overview mostly on the text of the ICH E11 Guideline [3] because of its practical character and wide international acceptance. We acknowledge the growing amount of highly competent reviews and commentaries available in this area, so the interested reader may found a lot of helpful material in those devoted resources [4].

Paediatric medicinal product development program. It is nowadays fully accepted that data on the appropriate use of medicinal products in the paediatric population should be generated unless the use of a specific medicinal product in paediatric patients is clearly inappropriate. The decision to proceed with a paediatric development program for a medicinal product, and the nature of that program, involve consideration of many factors (Tab. 1). The most important of those is the presence of a serious or life-threatening disease for which the medicinal product represents a 
potentially important advance in therapy. During clinical development, the timing of paediatric studies will depend on the medicinal product, the type of disease being treated, safety considerations, and the efficacy and safety of alternative treatments [5].

Table 1. Paediatric development program for a medicinal product

Factors to be considered*:

- the prevalence of the condition to be treated in the paediatric population;

- the seriousness of the condition to be treated;

- the availability and suitability of alternative treatments for the condition in the paediatric population, including the efficacy and the adverse event profile (including any unique paediatric safety issues) of those treatments;

- whether the medicinal product is novel or one of a class of compounds with known properties;

- whether there are unique paediatric indications for the medicinal product;

- the need for the development of paediatric-specific endpoints;

- $\quad$ the age ranges of paediatric patients likely to be treated with the medicinal product;

- unique paediatric (developmental) safety concerns with the medicinal product, including any nonclinical safety issues;

- $\quad$ potential need for paediatric formulation development;

*According to ICH E11 Note for Guidance on the Clinical Investigation of Medicinal Products in the Paediatric Population (CPMP/ICH/2711/99), p. 4 [3].

Timing of studies in paediatric populations. The studies of medicinal products in the paediatric population would usually not begin until the product is in the Phase 2 or 3 of its development. The relatively early or late start of these studies should consider the fact that the development of many new chemical entities is discontinued during or following Phase 1 and 2 studies in adults for lack of efficacy or an unacceptable side effect profile, and so a very early initiation of testing in paediatric patients might needlessly expose these patients to a compound that will be of no benefit. On the other hand, if the medicinal product represents a major therapeutic advance for the paediatric population, studies should begin as early as possible in its development. In any case, it is very important to carefully weigh benefit/risk and therapeutic need in deciding when to embark on paediatric studies.

Types of medicinal products in paediatric studies. There are various types of studies to be conducted in paediatric populations that can be distinguished according to the characteristics of a medicinal product with regard to its use in those populations [6]:

1. Studies of medicinal products for diseases predominantly or exclusively affecting paediatric patients. These are to be conducted entirely in the paediatric population except for initial safety and tolerability data, which will usually be obtained in adults. Some products may reasonably be studied only in the paediatric population even in the initial phases, e.g., when studies in adults would yield little useful information or expose them to inappropriate risk. Examples include surfactant for respiratory distress syndrome in preterm infants and therapies targeted at metabolic or genetic diseases unique to the paediatric population. 
2. Studies of medicinal products intended to treat serious or life-threatening diseases, occurring in both adults and paediatric patients, for which there are currently no or only limited therapeutic options.

3. Studies of medicinal products intended to treat other diseases and conditions. Here, there is less medical urgency to conduct the studies that usually begin at a later phase of clinical development of the product. If serious safety concerns exist, the studies are allowed in paediatric populations only after substantial post marketing experience in adults is obtained.

Paediatric studies - extrapolations of data. The ICH E11 Guideline outlines several specific issues with regard to paediatric efficacy studies, and with regard to extrapolations of data to/between different paediatric populations [7] (Tab. 2). Where efficacy studies are needed, it may be necessary to develop, validate and employ different endpoints for specific age and developmental subgroups. Measurement of subjective symptoms such as pain requires different assessment instruments for patients of different ages. In paediatric patients with chronic diseases, the response to a medicinal product may vary among patients not only because of the duration of the disease and its chronic effects but also because of the developmental stage of the patient. Many diseases in the preterm and term newborn infant are unique or have unique manifestations precluding extrapolation of efficacy from older paediatric patients and call for novel methods of outcome assessment.

Table 2. Considerations in extrapolation of data from adults to/between various paediatric populations*

- When a medicinal product is studied in paediatric patients in one region, the intrinsic (e.g. pharmacogenetic) and extrinsic (e.g., diet) factors that could impact on the extrapolation of data to other regions should be considered.

- When a medicinal product is to be used in the paediatric population for the same indication(s) as those studied and approved in adults, the disease process is similar in adults and paediatric patients, and the outcome of therapy is likely to be comparable, extrapolation from adult efficacy data may be appropriate. In such cases, pharmacokinetic studies in all the age ranges of paediatric patients likely to receive the medicinal product, together with safety studies, may provide adequate information for use by allowing selection of paediatric doses that will produce blood levels similar to those observed in adults. If this approach is taken, adult pharmacokinetic data should be available to plan the paediatric studies.

- When a medicinal product is to be used in younger paediatric patients for the same indication(s) as those studied in older paediatric patients, the disease process is similar, and the outcome of therapy is likely to be comparable, extrapolation of efficacy from older to younger paediatric patients may be possible. In such cases, pharmacokinetic studies in the relevant age groups of paediatric patients likely to receive the medicinal product, together with safety studies, may be sufficient to provide adequate information for paediatric use. 
- An approach based on pharmacokinetics is likely to be insufficient for medicinal products where blood levels are known or expected not to correspond with efficacy or where there is concern that the concentration-response relationship may differ between the adult and paediatric populations. In such cases, studies of the clinical or the pharmacological effect of the medicinal product would usually be expected.

- Where the comparability of the disease course or outcome of therapy in paediatric patients is expected to be similar to adults, but the appropriate blood levels are not clear, it may be possible to use measurements of a pharmacodynamic effect related to clinical effectiveness to confirm the expectations of effectiveness and to define the dose and concentration needed to attain that pharmacodynamic effect. Such studies could provide increased confidence that achieving a given exposure to the medicinal product in paediatric patients would result in the desired therapeutic outcomes. Thus, a PK/PD approach combined with safety and other relevant studies could avoid the need for clinical efficacy studies.

- In other situations where a pharmacokinetic approach is not applicable, such as for topically active products, extrapolation of efficacy from one patient population to another may be based on studies that include pharmacodynamic endpoints and/or appropriate alternative assessments. Local tolerability studies may be needed. It may be important to determine blood levels and systemic effects to assess safety.

- When novel indications are being sought for the medicinal product in paediatric patients, or when the disease course and outcome of therapy are likely to be different in adults and paediatric patients, clinical efficacy studies in the paediatric population would be needed.

*According to ICH E11 Note for Guidance on the Clinical Investigation of Medicinal Products in the Paediatric Population (CPMP/ICH/2711/99), p. 6 - 7 [3].

Pharmacokinetic studies. Those are generally performed to support formulation development and determine pharmacokinetic parameters in different age groups to support dosing recommendations. ICH E11 Guideline underlines that: bioavailability comparisons of paediatric formulations with the adult oral formulation typically should be done in adults; while definitive pharmacokinetic studies for dose selection across the age ranges of paediatric patients in whom the medicinal product is likely to be used should be conducted in the paediatric population. It also observes that pharmacokinetic studies in the paediatric population are generally conducted in patients with the disease. This may lead to higher inter-subject variability than studies in normal volunteers, but the data better reflect clinical use.

The volume of blood withdrawn should be minimized in paediatric studies. Several approaches can be used to minimize the amount of blood drawn and/or the number of venipunctures (Tab. 3).

Table 3. Approaches to minimize the amount of blood drawn and/or the number of venipunctures*

- $\quad$ use of sensitive assays for parent drugs and metabolites to decrease the volume of blood required per sample, 
- use of laboratories experienced in handling small volumes of blood for pharmacokinetic analyses and for laboratory safety studies (blood counts, clinical chemistry),

- collection of routine, clinical blood samples wherever possible at the same time as samples are obtained for pharmacokinetic analysis,

- the use of indwelling catheters, etc., to minimize distress,

- use of population pharmacokinetics and sparse sampling based on optimal sampling theory to minimize the number of samples obtained from each patient. Techniques include:

- $\quad$ sparse sampling approaches where each patient contributes as few as 2 to 4 observations at predetermined times to an overall "population area-under-thecurve",

- $\quad$ population pharmacokinetic analysis using the most useful sampling time points derived from modelling of adult data

*According to ICH E11 Note for Guidance on the Clinical Investigation of Medicinal Products in the Paediatric Population (CPMP/ICH/2711/99), p. 7 - 8 [3].

Safety. Medicinal products may affect physical and cognitive growth and development in children. Moreover, the adverse event profile in paediatric patients may differ from the one observed in adults. Because developing systems may respond differently, some adverse events and drug interactions that occur in paediatric patients may not be identified in adult studies. In addition, the dynamic processes of growth and development may not manifest an adverse event acutely, but at a later stage of growth and maturation. Long-term studies or surveillance data, either while patients are on chronic therapy or during the post-therapy period, may be needed to determine possible effects on skeletal, behavioural, cognitive, sexual, and immune maturation and development (see also the section "Pharmacovigilance" below).

Post-marketing information. Normally the paediatric database is limited at the time of a medicinal drug approval. Therefore, post marketing surveillance is particularly important. In some cases, long-term follow-up studies may be important to determine effects of certain medications on growth and development of paediatric patients. Post marketing surveillance and/or long-term follow-up studies may provide safety and/or efficacy information for subgroups within the paediatric population or additional information for the entire paediatric population.

Age classification of paediatric patients (Tab. 4). Any classification of the paediatric population into age categories is to some extent arbitrary. Decisions on how to stratify studies and data by age need to take into consideration developmental biology and pharmacology. The identification of which ages to study should be medicinal, product-specific (and clearly justified). It is a well established fact that there is a considerable overlap in developmental (e.g., physical, cognitive, and psychosocial) issues across the age categories. On the other hand, dividing the paediatric population into too many age groups may needlessly increase the number of patients required. In longer term studies, paediatric patients may move from one age category to another. The study design and statistical plans should prospectively take into account these changes. 
Table 4. Age classification of paediatric patients*

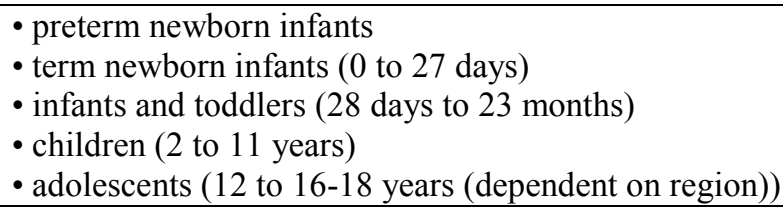

*According to ICH E11 Note for Guidance on the Clinical Investigation of Medicinal Products in the Paediatric Population (CPMP/ICH/2711/99), p. 9 [3].

\section{ETHICAL ISSUES IN PAEDIATRIC STUDIES}

The ICH E11 Guideline also outlines several ethical issues that are of special concern with regard to the paediatric clinical studies [8]. They are given briefly below, as follows. Moreover, the ad hoc expert group convened by the European Commission recently produced an excellent, more detailed guiding document on the ethics of clinical trials in paediatric populations [9]. We call upon some of those recommendations in the following text, as appropriate. The reader is advised, however, to make use of the full original text of the document to get a more detailed treatment of the ethical issues just briefly outlined here.

Justification. Concerns about conducting trials in the paediatric population should be balanced by the ethical concerns about giving medicinal products to a population in which they have not been appropriately tested. Public health threats from the use of untested medicinal products in the paediatric population can be safely addressed through the study of medicinal products for the paediatric population, which should be carefully controlled and monitored through the specific requirements for the protection of the paediatric population who take part in clinical trials laid down in Directive 2001/20/EC [10].

Vulnerability. The paediatric population represents a vulnerable subgroup. Therefore, special measures are needed to protect the rights of paediatric study participants and to shield them from undue risk. Information that can be obtained in a less vulnerable, consenting population should not be obtained in a more vulnerable population or one in which the patients are unable to provide individual consent. Studies in handicapped or institutionalized paediatric populations should be limited to diseases or conditions found principally or exclusively in these populations, or situations in which the disease or condition in these paediatric patients would be expected to alter the disposition or pharmacodynamic effects of a medicinal product.

Study design. To be of benefit to those participating in a clinical study, as well as to the rest of the paediatric population, a clinical study must be properly designed to ensure the quality and interpretability of the data obtained. Paediatric participants in clinical studies are expected to benefit from the clinical study except under the special circumstances (so-called non-therapeutic research). Protocols and investigations should be designed specifically for the paediatric population (not simply re-worked from adult protocols). They must also be approved as such by a research ethics committee. 
Ethics committees. The roles and responsibilities of ethics committees are critical to the protection of study participants. When protocols involving the paediatric population are reviewed, there should be ethics committees' members or experts consulted by the committee, who are knowledgeable in paediatric ethical, clinical, and psychosocial issues. Paediatric expertise [11] "goes beyond having professionally worked with children and could be defined on the basis of education, training and experience on the various aspects of child development, ethics and psychosocial aspects. Therefore, this would include i) physicians with paediatric qualification; ii) paediatric ethicists; iii) a paediatric pharmacologist, iv) qualified paediatric nurses or psychologists, etc. In addition to those qualifications, it is recommended that the experts demonstrate at least some years of experience in paediatric care and direct experience of clinical trials with children in similar age groups."

Considering the need for additional protection of children involved in clinical trials and with a view to providing an opinion on the protocol, the ethics committee should also check the content of the protocol with respect to paediatric protection (Tab. 5) [12].

Table 5. Issues to be examined by an ethics committee with regard to a clinical trial in children*

- Whether the trial replicates similar trials based on an identical hypothesis (which should be avoided).

- Protection and safety of children is ensured (including minimisation of risks, fear, pain and distress) and appropriate paediatric expertise is available at all trial sites.

- A justification is provided for the inclusion of children to achieve the trial objectives, for the choice of age groups. Depending on age groups, inclusion/exclusion criteria may need to include the outcome of a pregnancy test.

- Appropriate non-clinical data are available before the use of the product in children. Such data are defined, for example, in the ICH E11 guideline. This may include data from juvenile animal studies, modelling or other predictive studies.

- Extensive and comprehensive review of available evidence (including relevant publications) and experimental work on the investigational medicinal product should be available and reviewed to justify the initial hypothesis, the safety and the evaluation of expected benefit, and the age ranges of children to be included. The difference expected versus comparators should be described.

- The quality of the performance of the trial is such that it is likely that the results will be interpretable; monitoring, audit and quality assurance are described.

- The trial uses age-appropriate formulations of the medicinal product(s).

- An independent Data and Safety Monitoring Board (DSMB) with appropriate expertise in the conduct of clinical trials in children is identified in the protocol, unless otherwise justified.

- There are provisions in the protocol for systematic independent publications of results, within a reasonable timeframe, including when results are unfavourable.

- The protocol includes provision of the medicinal products to patients involved in trials after the completion of the trial where appropriate, unless the benefit to risk balance of the medicinal product tested proves negative. 
- The Ethics Committee and the Competent Authorities should ensure that the sponsor regularly monitors and re-examines the balance of risk and benefit of the research so that the health and well being of the children enrolled are safeguarded.

- For randomised trials there should be equipoise ("genuine uncertainty within the expert medical community [...] about the preferred treatment") at the beginning of the trial and no participants should receive care known to be inferior to existing treatments.

*Ethical Considerations for Clinical Trials on Medicinal Products Conducted with Paediatric Population. Recommendations of the ad hoc group for the development of implementing guidelines for Directive 2001/20/EC relating to good clinical practice in the conduct of clinical trials on medicinal products for human use. European Commission, 2008, 34 pgs, p. 14 [9].

Recruitment. Recruitment of study participants should occur in a manner free from inappropriate inducements either to the parent(s)/legal guardian or to the child/minor concerned. Reimbursement and subsistence costs may be covered. Any compensation should be reviewed by the ethics committee. The demographics of the region and of the disease being studied should be appropriately taken into account when recruiting individuals to be included in the study.

Consent and assent. Paediatric subject is as a rule legally unable to provide informed consent. Therefore paediatric study participants are dependent on their parent(s)/legal guardian/legal representative to assume responsibility for their participation. Informed consent should be obtained from those in accordance with the applicable national laws or regulations. In addition to this, all prospective participants should be informed to the fullest extent possible about the study in language and terms they are able to understand.

Where appropriate, paediatric participants should assent to enrol in a study (age of assent to be determined by the ethics committee or provided for by law). Participants of appropriate intellectual maturity should personally sign and date either a separately designed, written assent form or the written informed consent. Emancipated or mature minors (defined by local laws) may be capable of giving autonomous consent. In all cases, they should be made aware of their rights to decline to participate or to withdraw from the study at any time.

Attention should be paid to signs of undue distress in paediatric patients who are unable to clearly articulate their distress [9]. Although a participant's wish to withdraw from a study must be respected, there may be circumstances in therapeutic studies for serious or life-threatening diseases in which, in the opinion of the investigator and parent(s)/legal guardian, the welfare of a paediatric patient would be jeopardized by his or her failing to participate in the study. In this situation, continued parental (legal guardian) consent should be sufficient to allow participation in the study [9].

Minimizing risk. However important study may be to prove or disprove the value of a treatment, participants may suffer injury as a result of inclusion in the study, even if the whole community benefits. Every effort should be made to anticipate and reduce foreseeable hazards. Investigators should be fully aware before the start of a clinical study of all relevant preclinical and clinical toxicity of the medicinal product. To minimize risk in paediatric clinical studies, those conducting the study should be properly trained and experienced in studying the paediatric population, including the 
evaluation and management of potential paediatric adverse events. Every effort should be undertaken to minimize the number of participants and of procedures required. Mechanisms should be in place to ensure that a study can be rapidly terminated should an unexpected hazard be noted [9].

Minimizing discomfort and distress (Tab. 6). Repeated invasive procedures in paediatric patients may be painful or frightening. Discomfort can be minimized if studies are designed and conducted by investigators experienced in the treatment of such patients. Ethics committee should consider how many venipunctures are acceptable in obtaining blood samples for a protocol and ensure a clear understanding of procedures if an indwelling catheter fails to function over time. The participant's right to refuse further investigational procedures must be respected.

Table 6. Practical considerations to minimize discomfort and distress in paediatric clinical trials*

- $\quad$ personnel knowledgeable and skilled in dealing with the paediatric population and its age appropriate needs, including skill in performing paediatric procedures,

- a physical setting with furniture, play equipment, activities and food appropriate for age,

- the conduct of studies in a familiar environment such as the hospital or clinic where participants normally receive their care,

- $\quad$ approaches to minimize discomfort of procedures, such as:

- topical anaesthesia to place IV catheters,

- indwelling catheters rather than repeated venipunctures for blood sampling,

- collection of some protocol-specified blood samples when routine clinical samples are obtained.

*According to ICH E11 Note for Guidance on the Clinical Investigation of Medicinal Products in the Paediatric Population (CPMP/ICH/2711/99), p. 13 [3].

Pharmacovigilance. As pointed out in the respective EMEA guideline [13], the conduct of pharmacovigilance for medicines for paediatric use requires a special attention. Childhood diseases and disorders may be qualitatively and quantitatively different from their adult equivalents. This may affect either the benefit or the risk of therapies (or both), with a resulting impact on the risk/benefit balance. Chronic conditions may require chronic treatment and the susceptibility to adverse drug reactions (ADRs) may change throughout the patient's life-time according to age and the stage of growth and development. This is especially true for effects on the central nervous system. Growth and development during childhood reflect many underlying and interrelated processes. An interaction with these may result in ADRs not seen in the adult population, irrespective of the duration of treatment. In addition, the associated rapid changes in body mass, morphology and composition may present additional challenges in identifying and selecting the optimum dosing regimen. The problems are accentuated when the drugs involved are not authorised for paediatric use: unlicensed medicines or medicines used 'off-label' may have inadequate product information to support safe paediatric use; underreporting of adverse reactions may occur in relation to unlicensed or 'off-label' use due to legal and liability concerns. In addition, children may be unable to communicate adverse reactions clearly to their carers/ health care 
professionals or may not be aware of the adverse reactions as such. Premature babies may be at a much higher risk (for example due to slow elimination of xenobiotics, distribution barriers, physiological regulatory functions and "imprinting") and therefore need enhanced pharmacovigilance. Some more details are given in the Tab. 7.

\section{Table 7. Particular problems of pharmacovigilance in paediatrics*}

The lack of reliable data in paediatric populations:

- limited available safety data due to lack of clinical trials in the paediatric population;

- under- or over-dosing in some age groups due to lack of pharmacokinetics data or dose-finding studies (under-dosing may result in lack of benefit or development of resistance, over-dosing may result in an increase of Type A reactions);

- inadequate capture of events arising in the paediatric population from routinely available safety data

- $\quad$ incorrect dosing, use of products of less controlled quality or inappropriately high local concentrations leading to local adverse reactions due to lack of ageappropriate formulations.

Safety data in the paediatric population cannot necessarily be extrapolated from data in adults because certain adverse drug reactions (ADRs) may only be seen in the paediatric population depending on the maturation of organ systems (e.g. skin, airways, kidney, liver, blood-brain-barrier), metabolism, growth and development.

In particular:

- the pharmacokinetics and pharmacodynamics of a compound may be different in the paediatric population compared with adults and the former may be particularly vulnerable to ADRs or have different drug interaction profiles;

- the paediatric population may be more susceptible to ADRs from specific excipients;

- $\quad$ different ADRs may be relevant for different paediatric age groups and specific pharmacovigilance plans, strategies and activities should be tailored accordingly (in utero exposure may represent an additional risk factor);

- due to maturation, growth and development in the paediatric population may be susceptible to drug-induced growth and developmental disorders, as well as to delayed ADRs not seen in adults (long term follow-up data may be necessary to detect such effects);

- drug-induced "programming" may occur i.e. permanent effects may result from a drug exposure at a sensitive point in development ('critical window'); this is a particular consideration in foetal or neonatal life;

- $\quad$ certain ADRs may only be seen in the paediatric population, irrespective of effects on growth and development;

- in the case of life-long treatments for chronic diseases, the total duration of treatment is longer if started in childhood. This may expose the patient to increased risks of developing an ADR.

*According to the Guideline on Conduct of Pharmacovigilance for Medicines Used by the Paediatric Population, Committee for Medicinal Products for Human Use (CHMP): EMEA, London, 25 January 2007. Doc. Ref. EMEA/CHMP/PhVWP/235910/2005- rev.1, p. $4 .^{13}$ 


\section{NOTES ON THE APPLICABLE SLOVAKIAN LEGISLATION}

The most relevant applicable legislation with regard to biomedical research/CTs in children comprises the provisions contained in: 1) the Law No. 576/2004 Coll. on health care (as later multiply amended) and 2) the Law No. 326/2011 Coll. on medicinal drugs and medical devices [14].

The most relevant, specific provisions are given in the following sections of these laws:

a) Law No. 576/2004 Coll.:

- review of ethics in health care, establishment and work of ethics committees (§5),

- information to the patient and informed consent, including provisions in cases of persons unable to give informed consent, consent of a legal representative or guardian (\$6),

- detailed provisions on authorization and conduct of biomedical research ( $\$ 26$ $\S 34)$, including the research in persons unable to give informed consent (\$32), in pregnant or breastfeeding women (§33) and research in emergency situations (§34);

b) Law No. 326/2011 Coll.:

- detailed provisions covering clinical trials of medicinal drugs and medicinal products for human use $(\S 26, \S 29-\S 45)$, including:

- consent of a clinical trial participant (\$29, ind. (13), (14)),

- protection of a clinical trial participant $(\S 30)$,

- protection of minors $(\S 31)$,

- protection of adult participants that are unable to give a valid informed consent (§32).

In general, it can be stated that the protection of participants in the paediatric clinical trial in the Slovak Republic observes the same applicable legal and ethical standards that are in place in other countries of the European Union. The applicable national (Slovakian) legislation in this area is fully compatible with the EU law. As an example, we give here (Tab. 8) the translation of $\$ 31$ of the Law 326/2011 Coll. devoted to the protection of minors with regard to their participation in medicinal drugs/products clinical trials.

Table 8. Protection of minors with regard to their participation in clinical trials

\section{$\$ 31$}

\section{Protection of minors}

(1) Clinical trial in minors may only be conducted, if

a) informed consent of the parents or of the legal representative of the minor was obtained; this must express the presumed will of the minor and can be withheld at any time without consequences for the minor; 
b) the minor received from the investigator experienced in participation of minors in clinical trials the information about the objectives of the trial, its risks and benefits in the extent compatible with his/her ability to understand this information;

c) the investigator verified that the minor participant

1. expressed his/her agreement with the participation in the trial,

2. is able to make his/her own judgement about the objectives of the trial and to consider the information received about the trial,

3. is aware of his/her right not to consent to the participation in the trial, or to withdraw his/her consent at any time without any sanctions or consequences,

d) the parents or legal representative were offered no financial advantages or material advantages, except of the indemnity,

e) some direct benefits for the group of people with the disease are to be obtained from the clinical trial, and only if the trial is necessary for verification of data obtained in clinical trials conducted in persons able to give informed consent, or by other research methods; this trial is in direct connection with the clinical state (disease, illness, impairment) present in the minor participant, or the clinical trial according to its character is only possible to conduct in minor participants,

f) the clinical trial was designed with an aim to minimize the pain, discomfort, fear and other foreseeable risks connected with the disease, and the present level of the development of medicine was taken into account; the investigator is obliged to monitor continuously the level of risk and impairment of health,

g) the positive opinion with regard to the clinical trial was issued by the ethics committee with the experience in paediatrics, or after the committee's consultations with respective experts about the clinical problems, ethical problems, psychological problems and social problems connected to paediatrics.

(2) Interests of the minor always prevail upon the interests of the science and society.

*Law No. 326/2011 Coll. on medicinal drugs and medical devices. Original Slovak version: Č. 362 - Zákon z 13. septembra 2011 o liekoch a zdravotníckych pomôckach a o zmene a doplnení niektorých zákonov. Zbierka zákonov č. 362/2011, čiastka 117, s. 3110 - 3229, dostupné na internetovej adrese: http: http://www.zbierka.sk/zz/predpisy/default.aspx?Text=z\%c3\%a1kon+362\%2f2011 [14].

Translation by Jozef Glasa.

\section{CONCLUSIONS}

Clinical trials in paediatric populations are necessary. They are justified based on the scientific evidence available and perceived clinic needs of the patients stemming from the same population age range. The increased vulnerability of paediatric clinical trials participants in comparison to the adult patient populations clearly underlines the need for adequate protection of their rights, integrity and identity, health and well-being. In addition to the enactment of appropriate biomedical research/clinical trials and international and national legislations, as well as the development and observance of 
guidelines on good practices in this area, the education and training of investigators and other professionals involved in clinical trials in children and minors is necessary. The ultimate goal of these efforts is an enhanced availability of more effective and safer medicinal drugs for paediatric patients in Europe and globally. This provides for a strong ethical impetus in fostering these laudable scientific and professional developments.

\section{REFERENCES}

1. Based on the authors' presentation given at the $20^{\text {th }}$ Symposium of Clinical Pharmacy in honour of late Assoc. Prof. PharmDr. Lívia Magulová, PhD., Nitra, Slovakia, April 28 - 29, 2011.

2. Regulation (EC) No 1901/2006 of the European Parliament and the Council, as amended, on medicinal products for paediatric use ('Paediatric Regulation'). Available at: http://eurlex.europa.eu/LexUriServ/LexUriServ.do?uri=OJ:L:2006:378:0001:0019:EN:PDF (accessed Jan. 25, 2012)

3. ICH E11 Note for Guidance on the Clinical Investigation of Medicinal Products in the Paediatric Population (CPMP/ICH/2711/99). Available at: http://www.emea.europa.eu/pdfs/human/ich/271199EN.pdf (accessed Jan. 25, 2012)

4. ALRAVILLA, A. - MANFREDI, C. - BAIARDI, P. et al.: Impact of the new European paediatric regulatory framework on ethics committees: overview and perspectives. Acta Paediatr, 2012, 101, No. 1, p. e27-32. (Epub 2011 Jul 23).

5. ICH E11, p. $5-6$.

6. ICH E11, p. $5-6$.

7. ICH E11, p. $6-7$.

8. ICH E11, p. $11-13$.

9. Ethical Considerations for Clinical Trials on Medicinal Products Conducted with Paediatric Population. Recommendations of the ad hoc group for the development of implementing guidelines for Directive 2001/20/EC relating to good clinical practice in the conduct of clinical trials on medicinal products for human use. European Commission, 2008, 34 pgs. (further on "EC Recommendations 2008") Available at: http://ec.europa.eu/health/files/eudralex/vol-10/ethical_considerations_en.pdf (accessed Jan. 25, 2012)

10. Directive 2001/20/EC of the European Parliament and of the Council of 4 April 2001 on the approximation of the laws, regulations and administrative provisions of the Member States relating to the implementation of good clinical practice in the conduct of clinical trials on medicinal products for human use.

11. EC Recommendations 2008, p. 13.

12. EC Recommendations 2008, p. 13 - 14.

13. Committee for Medicinal Products for Human Use (CHMP): Guideline on Conduct of Pharmacovigilance for Medicines Used by the Paediatric Population, EMEA, London, 25 January 2007. Doc. Ref. EMEA/CHMP/PhVWP/235910/2005- rev.1, p. 3 - 4. Available at: http://www.ema.europa.eu/docs/en GB/document library/Scientific guideline/2009/09/WC5 00003764.pdf (accessed Jan. 25, 2012)

14. We refer in this text to the provisions contained in the law No. $326 / 2011$ Coll., which since December 2011 has superseded the original law No. 140/1998 Coll. on medicinal drugs and medical devices. The later version of the medicinal drugs and devices law was valid at the time of delivery of the original authors' presentation (see ref. 1). The text of the law available in Slovak language at: http://www.zbierka.sk (accessed Jan. 25, 2012) 
Registered: January, 2012

Accepted: February, 2012
Prof. Jozef Glasa, MD, PhD.,

Slovak Medical University in Bratislava

- Institute of Pharmacology, Clinical and Experimental

Pharmacology, Faculty of Medicine;

- Institute of Health Care Ethics, Faculty of Nursing and of Professional Health Studies

Limbová 12-14

83303 Bratislava

jozef.glasa@szu.sk

\title{
ETICKÉ OTÁZKY KLINICKÝCH SKÚŠANÍ U DETÍ
}

\author{
${ }^{1,2,4}$ Glasa, J. $-{ }^{1,4}$ Glasová, H.- ${ }^{3}$ Glasová, M.- ${ }^{2}$ Krčméryová, T. \\ ${ }^{1}$ Slovenská zdravotnícka univerzita, Ústav farmakológie a klinickej farmakológie \\ ${ }^{2}$ Slovenská zdravotnícka univerzit, Fakulta ošetrovatel'stva a zdravotníckych \\ odborných štúdií, Ústav zdravotníckej etiky \\ ${ }^{3}$ Univerzita Komenského v Bratislave, Pedagogická fakulta, Ústav psychologických a \\ logopédických štúdií \\ ${ }^{4}$ Ústav medicínskej etiky a bioetiky n.f.; Bratislava
}

Klinické skúšanie (KS) u detí má viaceré metodologické špecifiká, ktoré sa odrážajú v jeho etickej problematike a v hodnotení etickej akceptovatel'nosti daného protokolu etickou komisiou. Detský organizmus v porovnaní s dospelým vykazuje početné pato/fyziologické odlišnosti, ktoré navyše charakterizujú rýchle zmeny v priebehu rastu a vývinu diet’ata. Dnes sa nepochybuje o potrebe špecifických KS u detí, ktoré z mnohých dôvodov nemožno vykonat' u dospelých. Hoci deti nie sú schopné poskytnút' legálne platný informovaný súhlas a vždy je potrebné získat' súhlas ich zákonného zástupcu, pred zaradením diet’ata do KS je nevyhnutné získat' aj jeho primeraný súhlas/privolenie. V každom prípade sa musia rešpektovat' požiadavky minimalizácie bolesti, dyskomfortu, obáv/strachu diet’ata, jeho separácie od rodičov, najmä od matky. Špeciálnu problematiku predstavuje KS v neonatálnom období. Zo strany odbornej verejnosti, výrobcov liekov, ako aj z pozície inštitúcií Európskej únie sa venuje problematike KS u detí vel'ká pozornost'. Svedčia o tom početné vedecko-výskumné, odborné a legislatívne aktivity. V Slovenskej republike je problematika biomedicínskeho výskumu, vrátane KS u detí a mladistvých predmetom modernej legislatívnej úpravy. Zabezpečuje nielen maximálnu mieru ochrany v prípade účasti diet’at'a alebo mladistvého v biomedicínskom výskume alebo KS, ale zároveň poskytuje aj dostatočnú mieru právnej istoty pre zadávatel'ov a vykonávatel’ov výskumu/KS.

Acta Fac. Pharm. Univ. Comen., Suppl., 2012, VI, p. 6 - 20. 